\title{
A STUDY ON YOGHURT FORTIFIED WITH MUSHROOM (Agaricus Bisporus)
}

\author{
EL- DARDIRY, AMAL I. ${ }^{1}$, F. ABD EL-MALEK ${ }^{1}$ and REHAB H. GAB-ALLAH ${ }^{2}$
}

1. Dairy Chemistry Department, ANIMAL Production Research Institute, ARC, Giza, Egypt.

2. Dairy Technology Department, Food Technology Research Institute, ARC, Giza, Egypt.

(Manuscript received 6 July 2015)

\begin{abstract}
$\mathrm{Y}$ oghurt fortification with nutritional and health valuable mushroom, in relation to its numerous attributes beyond its probiotic benefits was the aim of the studied. Yoghurt milk was supplemented with Agaricus bisporus at levels 0\%, 5\% and $10 \%$. Thereafter, milk was inoculated with starter cultures, YC containing Streptococcus themophilus and Lactobacillus delbrueckii ssp. bulgaricus, YL containing Streptococcus themophilus, Lactobacillus delbrueckii ssp. bulgaricus, and Lb. acidophilus, YB containing Streptococcus themophilus, Lactobacillus delbrueckii ssp. bulgaricus and Bifidobacterium sp., and incubated at $42^{\circ} \mathrm{C}$ for complete coagulation (about $3 \mathrm{hr}$ ). There after, samples were kept at the refrigerator temperature $\left(5 \pm 1^{\circ} \mathrm{C}\right)$ for 3 weeks. The obtained results indicated that, yoghurt fortified with mushroom was significantly distinguished with increased values of protein, ash, fiber, $\mathrm{pH}$, curd tension, viscosity, amino acids, vitamins (riboflavin, niacin, $B_{12}$, biotin, $B_{1}$ and folate), minerals ( $\mathrm{Mg}, \mathrm{K}, \mathrm{Fe}, \mathrm{Zn}, \mathrm{P}, \mathrm{Cu}$, $\mathrm{Mn})$, organoleptic properiets and daily nutritional values (\%). Also the total counts of Str. themophilus, Lb. delbrueckii ssp. bulgaricus, $L b$. acidophilus, Bifidobacterium sp. were increased. While the values of fat, cholesterol, titratable acidity (T.A.\%), $\mathrm{Na}$ and $\mathrm{Ca}$ were decreased. The best fortification level with mushroom was $10 \%$ and the best bacterial starter culture was Bifidobacterium bifidum. Prolonging cold storage period of all samples was associated with increasing values of T.A., curd tension and viscosity.

Finally, it was concluded that, yoghurt beyond its ability to be probiotic food via its culturing with the gut strains, it could further carry more healthy benefits when it was fortified with mushroom at any level up to $10 \%$, but concerning bacteriological and organoleptic properties the level of $5 \%$ was preferable.
\end{abstract}

Key words: Mushroom, Agaricus bisporus, prebiotic, probiotics, yoghurt

\section{INTRODUCTION}

Yoghurt is a fermented milk product and generally a mixture of two species i.e. Lactobacillus delbrueckii ssp. Bulgaricus and Streptococcus thermophilus used. Usually it contains $12-14 \%$ total milk solids and has soft, friable custard like consistency with clean distinct acid flavor. Yoghurt supplies high quality protein and is 
an excellent source of calcium, phosphorus, potassium. It contains signtificant quantities of vitamins (Vinderola et al., 2000).

Edible mushrooms have been widely used as human food for centuries and have been appreciated for texture and flavours as well as some medicinal and tonic attributes. However, the awareness of mushrooms as a healthy food and as an important source of biological active substances with medicinal value has only recently emerged. Various activities of mushrooms have been studied which include antibacterial, antifungal, antioxidant, antiviral, antitumor, cytostatic, immunosuppressive, antiallergic, antiatherogenic hypoglycaemic, anti-inflammatory and hepatoprotective activities.Most researches are focused antioxidant and antitumor activities, (Lindequist et al., 2005).

Dietary fibers may play an important role in the prevention of some degenerative diseases e.g. coronary heart disease, stroke, hypertension, diabetes, obesity and certain gastrointestinal disorders. Furthermore, increased consumption of dietary fibers improved serum lipid concentrations, lowered blood pressure, improved blood glucose control in diabetes, promoted regularity, and improved immunety function. Dietary fibers can also impart some functional properties to foods, e.g., increase water and oil holding capacities, emulsifications and/or gel formation (Dervisoglu\&Yazici 2006).

One way in which foods can be modified to become functional is by addition of probiotics. The word probiotic was originated from Greek word meaning "for life".Probiotic foods are defined as foods containing live microorganisms believed to activity enhance health by improving the balance of microflora in the gut. Prebiotics are non-digestible dietary components that pass through the colon and selectively stimulate the proliferation and/or activity of probiotic bacteria in the colon. Synbiotic is a product in which both a probiotic and prebiotic are combined in a single product. It is defined as a mixture of probiotics and prebiotics that beneficially affects the host by improving the survival and implantation of probiotic in gastrointestinal tract (Gibson, 1999).

In recent years, there has been a growing interest in using probiotic microorganisms as dietary adjuncts in the dairy industry. Products have been developed and are on the market worldwide. Among the dairy products with live cultures, probiotics ice cream or fermented frozen desserts which, gaining popularity. Moreover, the growing demand for healthy foods is stimulating innovation and new product development in the food industry throughout the world (Mattila-Sandholm et al., 2002). 
Therefore, the aim of this study was devoted to utilize of Mushrom in bio yoghurt manufacture to increase and improvement functional, healthy and nutritional properties.

\section{MATERIALS AND METHODS}

\section{Materials}

\section{Milk:}

Fresh buffalo's milk was obtained from the experimental station at Mahalet Moussa, Animal production Research Institute, Egypt. The milk was standardized to $4 \%$ fat.

\section{Starter cultures:}

Freeze dried conventional yoghurt starter culture (FD-DVS YC-X11) containing Lactobacillus delbrueckii ssp. bulgaricus and Streptococcus thermophilus was (YC), (La-5) contain Lb. acidophilus and (Bb-46) contain Bifidobacterium bifidum (B) were obtained from Chr. Hansen A/S, DK-2970 Horsholm, Denmark.

Mushroom (Agaricus bisporus):

Mushroom was obtained from the local market in cairo, Egypt.

Table 1. The chemical composition of Agaricus bisporus.

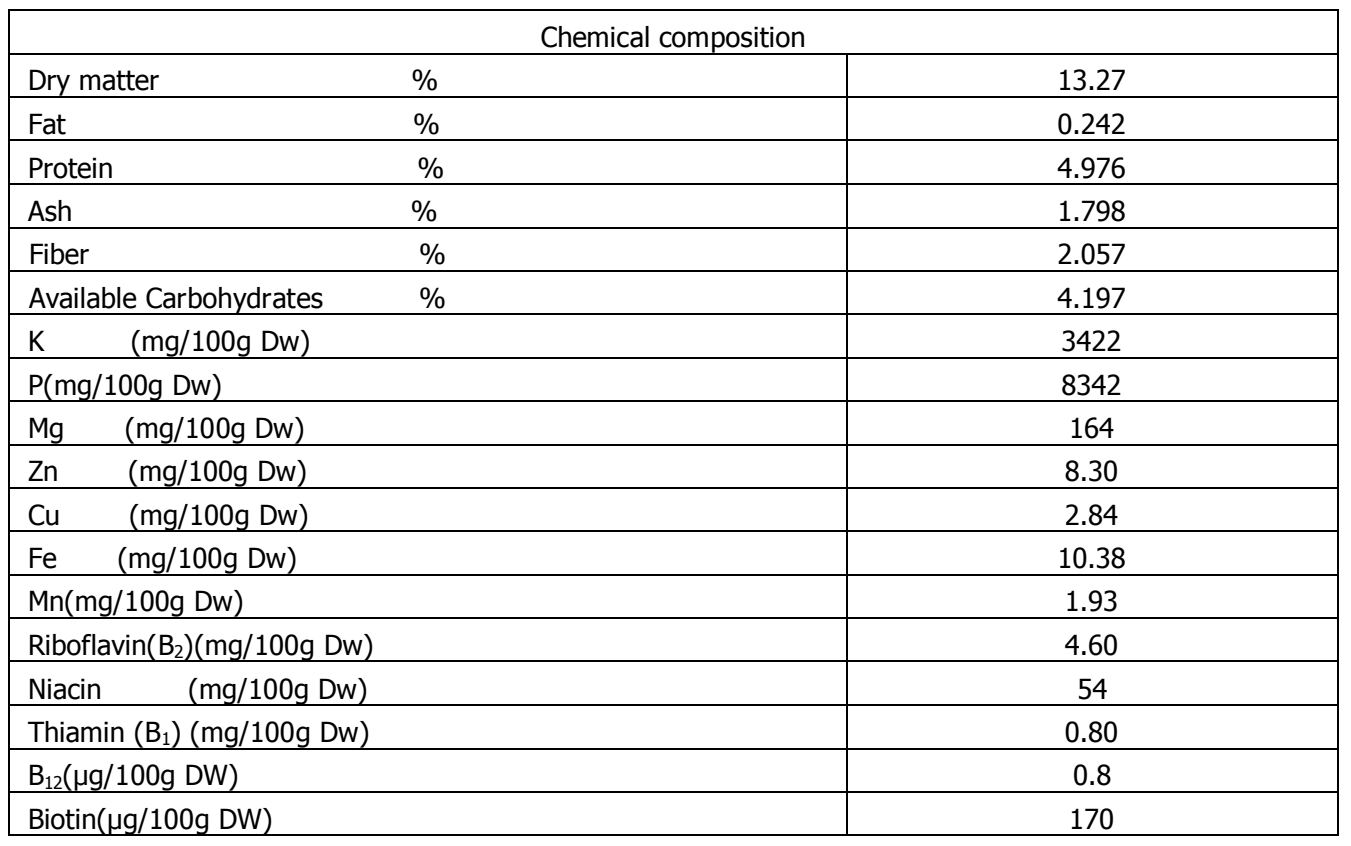

Total Protein $=\mathrm{N} \times 4.38$

\section{Experimental procedures}

\section{Preparation of bacterial starter culture}

Lyophilized bacterial cultures were separately inoculated in skimmed milk which was previously autoclaved at $121^{\circ} \mathrm{C} / 15 \mathrm{~min}$. Then incubated at $42^{\circ} \mathrm{C}$ for the $\mathrm{YC}$, at $37^{\circ} \mathrm{C}$ for the $\mathrm{YL}$ and $\mathrm{YB}$ type. The complete curdling occurred within $3 \mathrm{~h}$. Starter cultures were freshly used. 


\section{Preparation of cooked mushroom:}

Cooked mushroom was prepared by soaking the cleaned small pieces of mushroom in water (1 kg mushroom/ $200 \mathrm{ml}$ water) and boiled for $10 \mathrm{~min}$, then the mixture (mushroom and water) was minced and blended to get very fine paste and kept frozen until used.

\section{Preparation of fermented milk (Fig.1).}

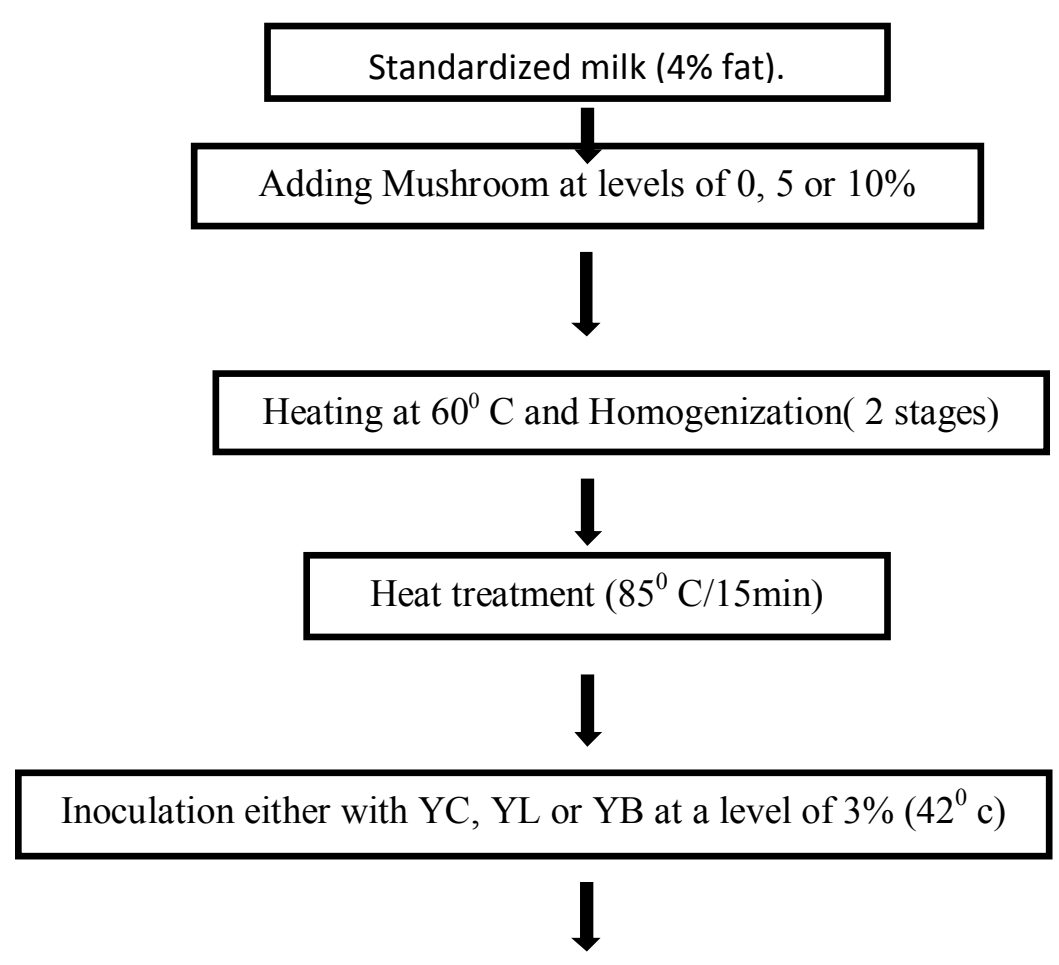

Filling into $100 \mathrm{ml}$ polystyrene containers, covering and incubation at $42^{\circ} \mathrm{C} / 3 \mathrm{~h}$.

Cold storage at $5^{\circ} \mathrm{C}$ for 3 weeks

\section{Analytical methods}

Dry matter, fat, total nitrogen and titratable acidity were determined according to AOAC (2007). The pH value was measured electrometrically using Lab. $\mathrm{pH}$ meter with a glass electrode, Hanna digital pH meter. The mineral contents were determined according to the method described by the AOAC (2007) using atomic absorption spectrometer. The amino acids contents were determined by high performance amino acids analyzer according to the method described by AOAC(2012).The viscosity of yoghurt was determined by Brookifield DV- E viscometer 
using spindle 5 at rpm 20 in $200 \mathrm{ml}$ of yoghurt sample. The temperature was maintained at $25^{\circ} \mathrm{C}$ and viscosity value was expressed in centipoises (cp). Fiber contents were determined as described by AOAC (2007).Total cholesterol was determinedas described by Pantulu et al. (1975). Carbohydrate content of all samples was calculated as described by Ceirwyn, (1995) using the following formula:

$\%$ Available carbohydrates $=100-(\%$ fat $+\%$ protein $+\%$ ash $+\%$ fiber $+\%$ moisture $)$.

\section{Microbiological analyses}

The count of $L b$. delbrueckii ssp. bulgaricus was enumerated using MRS agar medium as described by Gueimonde et al. (2003). Culture was incubated anaerobically for 2 days at $37^{\circ} \mathrm{C}$.

Whilst, Str. thermophilus, Lb. acidophilus and Bifidobacterium sp.were enumerated using M17 agar, MRS-salicin agar and MRS agar media, respectively after the incubation at $37^{\circ} \mathrm{C}$ for $72 \mathrm{~h}$. as in Dave \& Shah (1996).

\section{Organoleptic evaluation}

Sensory evaluation of yoghurt samples was applied during storage period by the staff members of Dairy Chemistry Department, Animal Production Research Institute, according to Tamime and Robinson (1999) using the yoghurt evaluation scheme III approved by the American Dairy Science Association.

\section{Nutritional value of yoghurt}

Daily values of nutrients for yoghurt were calculated using food tables (FDA, 2013)

\section{Statistical analysis}

The data obtained were statistical analysed according to statistical analyses system user's guide (SAS, 1996).

\section{RESULTS AND DISCUSSION}

\section{Gross composition of yoghurt}

Data in Table (2) indicated that the supplementing with $A$. bisporus led to significant differences in the dry matter (DM) contents of the resultant yoghurt. All contents calculated on dry basis. Content of protein, ash and fiber increased while the fat decreased significantly by increasing the level of $A$. bisporus. It is worthy to mention that all DM contents are, in general, in coincidence with the Egyptian Organization for Standards and Quality (EOSQ, 2010). 
Table 2. Gross composition of yoghurt as affected either by the level of Supplementing with Agaricus bisporus or the type of bacterial starter culture.

\begin{tabular}{|c|c|c|c|c|c|c|c|c|c|}
\hline \multirow{3}{*}{ Component (\%) } & \multicolumn{9}{|c|}{ levels of supplementing with mushroom } \\
\hline & \multicolumn{3}{|c|}{$0.0 \%$ (control) } & \multicolumn{3}{|c|}{$5 \%$} & \multicolumn{3}{|c|}{$10 \%$} \\
\hline & YC & YL & YB & YC & $\mathrm{YL}$ & YB & YC & $\mathrm{YL}$ & YB \\
\hline Dry matter & 12.780 & 12.782 & 12.784 & 12.804 & 12.806 & 12.805 & 12.829 & 12.830 & 12.829 \\
\hline Fat & $3.940^{\mathrm{a}, \mathrm{a}}$ & $3.940^{\mathrm{a}, \mathrm{a}}$ & $3.942^{\mathrm{a}, \mathrm{a}}$ & $3.756^{\mathrm{b}, \mathrm{a}}$ & $3.755^{b, a}$ & $3.755^{\mathrm{b}, \mathrm{a}}$ & $3.571^{c, a}$ & $3.570^{c, a}$ & $3.570^{c . a}$ \\
\hline Protein & $3.720^{\mathrm{b}, \mathrm{a}}$ & $3.722^{b, a}$ & $3.721^{\mathrm{b}, \mathrm{a}}$ & $3.783^{\mathrm{ab}, \mathrm{a}}$ & $3.783^{\mathrm{ab}, \mathrm{a}}$ & $3.784^{\mathrm{ab}, \mathrm{a}}$ & $3.846^{a, a}$ & $3.846^{a, a}$ & $3.845^{a, a}$ \\
\hline Ash & $0.830^{\mathrm{b}, \mathrm{a}}$ & $0.831^{\mathrm{b}, \mathrm{a}}$ & $0.831^{\mathrm{b}, \mathrm{a}}$ & $0.879^{\mathrm{ab}, \mathrm{a}}$ & $0.880^{\mathrm{ab}, \mathrm{a}}$ & $0.879^{\mathrm{ab}, \mathrm{a}}$ & $0.928^{\mathrm{a}, \mathrm{a}}$ & $0.927^{\mathrm{a}, \mathrm{a}}$ & $0.928^{a, a}$ \\
\hline Fiber & - & - & - & $0.103^{b, a}$ & $0.103^{b, a}$ & $0.103^{b, a}$ & $0.206^{a, a}$ & $0.205^{a, a}$ & $0.206^{a, a}$ \\
\hline Total Carbohydrates & $4.290^{\mathrm{a}, \mathrm{a}}$ & $4.289^{\mathrm{a}, \mathrm{a}}$ & $4.290^{\mathrm{a}, \mathrm{a}}$ & $4.283^{\mathrm{a}, \mathrm{a}}$ & $4.285^{\mathrm{a}, \mathrm{a}}$ & $4.284^{\mathrm{a}, \mathrm{a}}$ & $4.278^{\mathrm{a}, \mathrm{a}}$ & $4.282^{\mathrm{a}, \mathrm{a}}$ & $4.280^{a, a}$ \\
\hline
\end{tabular}

The letters before comma possess the factor of mushroom level. While those after comma possess the factor of the starter. The means with the same letter at any position did not significantly differ $(P>0.05)$.

YC= Yoghurt culture, (Str. thermophilus + Lb. bulgaricus).

$\mathbf{Y L}=$ Yoghurt culture + Lactobacillus acidophilus (1:1).

$\mathbf{Y B}=$ Yoghurt culture + Biifidobacterium bifidum (1:1) 
The obtained results indicated that, neither dry matter nor total carbohydrates were influenced by the type of bacterial starter culture at any level of $A$. bisporus supplementation.

Moreover, there wassignificant reductionin the fat content of yoghurt associated with the increase in supplementing level of $A$. bisporus especially at a level of $10 \%$. The fat content of all treatments agreed with legal standards of EOSQ (2010). With regard to the protein, ash and fiber contents of yoghurt, data illustrated in table (2) confirmed that, the protein, ash and fiber contents increased significantly $(P<$ 0.001 ) as the supplementing level with $A$. bisporus increased. The maximum was at a level of $10 \%$.

Regarding the total carbohydrates content of yoghurt, data given in table (2) stated that neither the kind of starter nor the level of supplementing $A$. bisporus led to any significant differences $(P>0.05)$ in the total carbohydrates content of yoghurt.

\section{Lactic acid bacteria population of yoghurt}

Bacterial counts enumerated in Tables (3 and 4) revealed that, the Str. thermophilus count was higher than that of $L b$. delbrueckii ssp. bulgaricus or $L b$. acidophilus or Bifidobacterium bifidum in all treatments. Rasic and Kurmann (1978) reviewed that Str. thermophilus grows faster at the beginning of lactic acid fermentation, outnumbering $L b$. delbrueckii ssp. bulgaricus by 3 or 4 times often the $1^{\text {st }} \mathrm{h}$. Moreover, the fortification with $A$. bisporus led to promote the growth of all strains of yoghurt bacterial starter cultures. This promoting action achieved their maximum when $A$. bisporus was added at level of $5 \%$. Similar observations were reported by Chou et al. (2013).

During cold storage period, both counts of Str. thermophilus and $L b$. acidophilus increased significantly along the first week, then decreased gradually thereafter (Tables, 3 and 4). While the count of $L b$. delbrueckii ssp. bulgaricus started to decrease from the beginning of cold storage period. The count of Bifidobacterium bifidum still high as till the first week and began to reduce. These findings are in coincidence with those reviewed by Rasic and Kurmann (1978) who reported that, the total count of viable yoghurt bacterial ranges between $200 \times 10^{6}$ and $1000 \times 10^{6} \mathrm{cfu} /$ $\mathrm{ml}$ of fresh yoghurt. During the storage of yoghurt even at $5^{\circ} \mathrm{C}$, the number of lactic acid bacteria decreases reaching $1 \times 10^{6} \mathrm{cfu} / \mathrm{ml}$ after 80 days at $5^{\circ} \mathrm{C}$. 
Table 3. Counts of streptococcus thermophilus and Lactobacillus delbrueckii ssp. bulgaricus (cfu $\times 10^{7} / \mathrm{g}$ ) of yoghurt as affected either by the level of supplementing with Agaricus bisporus or the type of bacterial starter culture during storage period.

\begin{tabular}{|c|c|c|c|c|c|c|c|c|c|}
\hline \multirow{3}{*}{$\begin{array}{c}\text { Cold } \\
\text { storage } \\
\text { period } \\
\text { (week) }\end{array}$} & \multicolumn{9}{|c|}{ level of supplementing with mushroom } \\
\hline & \multicolumn{3}{|c|}{$0.0 \%$ (control) } & \multicolumn{3}{|c|}{$5 \%$} & \multicolumn{3}{|c|}{$10 \%$} \\
\hline & YC & YL & YB & YC & YL & YB & YC & YL & YB \\
\hline & & & \multicolumn{5}{|c|}{ streptococcus thermophilus (cfu x $10^{7} / \mathrm{g}$ ) } & & \\
\hline 0 & $540^{\mathrm{b}, \mathrm{a}, \mathrm{a}}$ & $250^{b, b, a}$ & $245^{b, b, a}$ & $580^{a, a, a}$ & $247^{\mathrm{a}, \mathrm{b}, \mathrm{a}}$ & $247^{\mathrm{a}, \mathrm{b}, \mathrm{a}}$ & $540^{\mathrm{b}, \mathrm{a}, \mathrm{a}}$ & $244^{b, b, a}$ & $240^{b, b, a}$ \\
\hline 1 & $550^{b, a, b}$ & $260^{b, b, b}$ & $246^{b, b, b}$ & $590^{a, a, b}$ & $249^{a, b, b}$ & $248^{a, b, b}$ & $545^{b, a, b}$ & $246^{b, b, b}$ & $243^{b, b, b}$ \\
\hline 2 & $390^{b, a, c}$ & $234^{b, b, c}$ & $230^{b, b, c}$ & $420^{a, a, c}$ & $236^{a, b, c}$ & $234^{a, b, c}$ & $380^{b, a, c}$ & $232^{b, b, c}$ & $230^{b, b, c}$ \\
\hline \multirow[t]{2}{*}{3} & $345^{b, a, d}$ & $227^{b, b, d}$ & $226^{b, b, d}$ & $360^{\mathrm{a}, \mathrm{a}, \mathrm{d}}$ & $229^{a, b, d}$ & $227^{a, b, d}$ & $330^{b, a, d}$ & $223^{b, b, d}$ & $222^{b, b, d}$ \\
\hline & & & \multicolumn{5}{|c|}{ Lactobacillus delbrueckii ssp. bulgaricus } & & \\
\hline 0 & $170^{\mathrm{b}, \mathrm{a}, \mathrm{a}}$ & $82^{b, b, a}$ & $80^{\mathrm{b}, \mathrm{b}, \mathrm{a}}$ & $190^{\mathrm{a}, \mathrm{a}, \mathrm{a}}$ & $87^{a, b, a}$ & $81^{a, b, a}$ & $170^{\mathrm{c}, \mathrm{a}, \mathrm{a}}$ & $79^{c, b, a}$ & $60^{c, b, a}$ \\
\hline 1 & $80^{\mathrm{b}, \mathrm{a}, \mathrm{b}}$ & $44^{\mathrm{b}, \mathrm{b}, \mathrm{b}}$ & $41^{\mathrm{b}, \mathrm{b}, \mathrm{b}}$ & $99^{\mathrm{a}, \mathrm{a}, \mathrm{b}}$ & $54^{a, b, b}$ & $57^{a, b, b}$ & $45^{c, a, b}$ & $58^{c, b, b}$ & $46^{\mathrm{c}, \mathrm{b}, \mathrm{b}}$ \\
\hline 2 & $45^{\mathrm{b}, \mathrm{a}, \mathrm{c}}$ & $5.4^{b, b, c}$ & $5.1^{b, b, c}$ & $58^{\mathrm{a}, \mathrm{a}, \mathrm{c}}$ & $5.8^{\mathrm{a}, \mathrm{b}, \mathrm{c}}$ & $5.3^{\mathrm{a}, \mathrm{b}, \mathrm{c}}$ & $28^{c, a, c}$ & $4.9^{c, b, c}$ & $4.8^{\mathrm{c}, \mathrm{b}, \mathrm{c}}$ \\
\hline 3 & $13^{\mathrm{b}, \mathrm{a}, \mathrm{d}}$ & $2.8^{b, b, d}$ & $2.5^{b, b, c}$ & $17^{\mathrm{a}, \mathrm{a}, \mathrm{d}}$ & $3.1^{a, b, d}$ & $2.7^{\mathrm{a}, \mathrm{b}, \mathrm{d}}$ & $11^{c, a, d}$ & $2.8^{c, b, d}$ & $1.1^{\mathrm{c}, \mathrm{b}, \mathrm{d}}$ \\
\hline
\end{tabular}

The letters before comma possess the factor of mushroom level. While those after comma possess the factor of the starter and storage period, respectively. The means with the same letter at any position were not significant $(P>0.05)$

The results showed that viability of probiotic of all samples decreased with storage time and the count of Bifidobacterium bifidum was the lowest among the probiotics after $21 \mathrm{~d}$ of cold storage. Similar observations were reported by Chou et al. (2013).

Generally, it is worthy to mention that, the bacterial counts of all yoghurt treatments, in relation either to the kind and level of supplementing or to the bacterial starter culture, whether when fresh or along cold storage period, stilled conforming the figures provided by Codex Alimentarius commission of FAO/ WHO (2002) which approved an international standard as established a minimum of $10^{7} / \mathrm{g}$ for the starter cultures of fermented milks and a minimum of $10^{6} / \mathrm{g}$ for specific starter bacteria for which a claim is made for specific microorganism that has been added as supplement. 
Table 4. Counts of Lactobacillus acidophilus and Bifidobacterium sp. (cfu $\times 10^{7} / \mathrm{g}$ ) in $\mathrm{YL}$ and $\mathrm{YB}$ yoghurt as affected by level of supplementing with Agaricus bisporus during storage period

\begin{tabular}{|c|c|c|c|}
\hline \multirow{2}{*}{ Cold storage period (week) } & \multicolumn{3}{|c|}{ level of supplementing with mushroom } \\
\cline { 2 - 4 } & $0.0 \%$ (control) & $5 \%$ & $10 \%$ \\
\hline & \multicolumn{3}{|c|}{ Lactobacillus acidophilus } \\
\hline 0 & $46^{\mathrm{b}, \mathrm{a}}$ & $50^{\mathrm{a}, \mathrm{a}}$ & $46^{\mathrm{b}, \mathrm{a}}$ \\
\hline 1 & $47^{\mathrm{b}, \mathrm{a}}$ & $53^{\mathrm{a}, \mathrm{a}}$ & $45^{\mathrm{b}, \mathrm{a}}$ \\
\hline 2 & $23^{\mathrm{b}, \mathrm{b}}$ & $20^{\mathrm{a}, \mathrm{b}}$ & $19^{\mathrm{b}, \mathrm{b}}$ \\
\hline 3 & $3.0^{\mathrm{b}, \mathrm{c}}$ & $3.4^{\mathrm{a}, \mathrm{c}}$ & $2.7^{\mathrm{b}, \mathrm{c}}$ \\
\hline & & Bifidobacterium bifidum & $39^{\mathrm{b}, \mathrm{a}}$ \\
\hline 1 & $40^{\mathrm{b}, \mathrm{a}}$ & $42^{\mathrm{a}, \mathrm{a}}$ & $38^{\mathrm{b}, \mathrm{a}}$ \\
\hline 2 & $38^{\mathrm{b}, \mathrm{a}}$ & $43^{\mathrm{a}, \mathrm{a}}$ & $10^{\mathrm{b}, \mathrm{b}}$ \\
\hline 3 & $17^{\mathrm{b}, \mathrm{b}}$ & $19^{\mathrm{a}, \mathrm{b}}$ & $0.9^{\mathrm{b}, \mathrm{c}}$ \\
\hline
\end{tabular}

The letters before comma possess the factor of mushroom level. While those after comma possess the factor of the starter and storage period, respectively. The means with the same letter at any position were not significant $(P>0.05)$.

\section{Chemical and Physical properties}

\section{Titratable acidity (\%) and $\mathrm{pH}$ value}

The results of table (5) showed that, the control had the highest T.A\% when fresh, whilethe treatment with $A$. bisporus at level $10 \%$ had lower value in T.A\% and the $\mathrm{pH}$ value was higher than the treatment supplemented with $A$. bisporus at level $5 \%$.

Moreover, the level of acidity produced by $\mathrm{YL}$ starter culture in yoghurt was significantly the highest $(p<0.001)$.

Generally, the prolonging of cold storage period of yoghurt caused a significant increase $(p<0.001)$ in T.A\% and significant reduction $(p<0.001)$ in $\mathrm{pH}$ value. 
Table 5. Titratable acidity (TA) and pH value of yoghurt as affected either by the level of supplementing with Agaricus bisporus or the type of bacterial starter culture during storage period.

\begin{tabular}{|c|c|c|c|c|c|c|c|c|c|}
\hline \multirow{3}{*}{$\begin{array}{l}\text { Cold } \\
\text { storage } \\
\text { period } \\
\text { (week) }\end{array}$} & \multicolumn{9}{|c|}{ level of supplementing with mushroom } \\
\hline & \multicolumn{3}{|c|}{$0.0 \%$ (control) } & \multicolumn{3}{|c|}{$5 \%$} & \multicolumn{3}{|c|}{$10 \%$} \\
\hline & YC & YL & YB & YC & $\mathrm{YL}$ & YB & YC & $\mathrm{YL}$ & YB \\
\hline \multicolumn{10}{|c|}{ T.A(\%) } \\
\hline 0 & $0.86^{\mathrm{a}, \mathrm{b}, \mathrm{a}}$ & $0.86^{\mathrm{a}, \mathrm{a}, \mathrm{a}}$ & $0.78^{\mathrm{a}, \mathrm{c}, \mathrm{a}}$ & $0.83^{\mathrm{b}, \mathrm{b}, \mathrm{a}}$ & $0.85^{b, a, a}$ & $0.76^{b, c, a}$ & $0.82^{\mathrm{b}, \mathrm{b}, \mathrm{a}}$ & $0.83^{\mathrm{b}, \mathrm{a}, \mathrm{a}}$ & $0.75^{\mathrm{b}, \mathrm{c}, \mathrm{a}}$ \\
\hline 1 & $0.96^{\mathrm{a}, \mathrm{b}, \mathrm{b}}$ & $1.06^{\mathrm{a}, \mathrm{a}, \mathrm{b}}$ & $0.87^{\mathrm{a}, \mathrm{c}, \mathrm{b}}$ & $0.91^{\mathrm{b}, \mathrm{b}, \mathrm{b}}$ & $0.97^{b, a, b}$ & $0.82^{b, c, b}$ & $0.90^{\mathrm{b}, \mathrm{b}, \mathrm{b}}$ & $0.94^{\mathrm{b}, \mathrm{a}, \mathrm{b}}$ & $0.80^{\mathrm{b}, \mathrm{c}, \mathrm{b}}$ \\
\hline 2 & $1.15^{\mathrm{a}, \mathrm{b}, \mathrm{c}}$ & $1.18^{\mathrm{a}, \mathrm{a}, \mathrm{c}}$ & $0.93^{\mathrm{a}, \mathrm{c}, \mathrm{c}}$ & $1.02^{\mathrm{b}, \mathrm{b}, \mathrm{c}}$ & $1.11^{b, a, c}$ & $0.89^{b, c, c}$ & $1.05^{\mathrm{b}, \mathrm{b}, \mathrm{c}}$ & $1.08^{\mathrm{b}, \mathrm{a}, \mathrm{c}}$ & $0.93^{b, c, c}$ \\
\hline 3 & $1.25^{\mathrm{a}, \mathrm{b}, \mathrm{d}}$ & $1.27^{\mathrm{a}, \mathrm{a}, \mathrm{d}}$ & $1.11^{\mathrm{a}, \mathrm{c}, \mathrm{d}}$ & $1.19^{b, b, d}$ & $1.23^{b, a, d}$ & $1.01^{b, c, d}$ & $1.20^{\mathrm{b}, \mathrm{b}, \mathrm{d}}$ & $1.24^{\mathrm{b}, \mathrm{a}, \mathrm{d}}$ & $1.07^{\mathrm{b}, \mathrm{c}, \mathrm{d}}$ \\
\hline \multicolumn{10}{|c|}{$\mathrm{pH}$} \\
\hline 0 & $4.63^{c, b, a}$ & $4.61^{c, c, a}$ & $4.80^{c, a, a}$ & $4.66^{\mathrm{b}, \mathrm{b}, \mathrm{a}}$ & $4.63^{b, c, a}$ & $4.83^{\mathrm{b}, \mathrm{a}, \mathrm{a}}$ & $4.68^{\mathrm{a}, \mathrm{b}, \mathrm{a}}$ & $4.67^{\mathrm{a}, \mathrm{c}, \mathrm{a}}$ & $4.85^{\mathrm{a} a \mathrm{a}, \mathrm{a}}$ \\
\hline 1 & $4.52^{\mathrm{c}, \mathrm{b}, \mathrm{b}}$ & $4.46^{c, c, b}$ & $4.71^{c, a, b}$ & $4.56^{b, b, b}$ & $4.50^{b, c, b}$ & $4.75^{\mathrm{b}, \mathrm{a}, \mathrm{b}}$ & $4.59^{\mathrm{a}, \mathrm{b}, \mathrm{b}}$ & $4.53^{\mathrm{a}, \mathrm{c}, \mathrm{b}}$ & $4.78^{\mathrm{a}, \mathrm{a}, \mathrm{b}}$ \\
\hline 2 & $4.36^{\mathrm{c}, \mathrm{b}, \mathrm{c}}$ & $4.31^{c, c, c}$ & $4.60^{c, a, c}$ & $4.43^{b, b, c}$ & $4.34^{b, c, c}$ & $4.68^{\mathrm{b}, \mathrm{a}, \mathrm{c}}$ & $4.45^{\mathrm{a}, \mathrm{b}, \mathrm{c}}$ & $4.35^{\mathrm{a}, \mathrm{a}, \mathrm{c}}$ & $4.65^{\mathrm{a} a \mathrm{a}, \mathrm{c}}$ \\
\hline 3 & $4.19^{\mathrm{c}, \mathrm{b}, \mathrm{d}}$ & $4.15^{c, c, d}$ & $4.44^{c, a, d}$ & $4.23^{b, b, d}$ & $4.19^{b, c, d}$ & $4.48^{\mathrm{b}, \mathrm{a}, \mathrm{d}}$ & $4.25^{\mathrm{a}, \mathrm{b}, \mathrm{d}}$ & $4.18^{\mathrm{a}, \mathrm{c}, \mathrm{d}}$ & $4.50^{\mathrm{a}, \mathrm{a}, \mathrm{d}}$ \\
\hline
\end{tabular}

The letters before comma possess the factor of mushroom level. While those after comma possess the factor of the starter and storage period, respectively. The means with the same letter at any position were not significanly different $(P>0.05)$

\section{Amino acids content}

It could be noticed from the data in table (6), that there were significant increases in the essential amino acids andnon essential amino acids content of yoghurt associated with the proportional of in the supplementing level with $A$. bisporus.

Data showed that, neither the kind of starter nor the level of supplementing with $A$. bisporus led to any significant differences $(P<0.05)$ in the essential amino acids andnon essential amino acids content of all yoghurt treatments.

Data in Table (6) indicated that the yoghurt fortified with levels of $A$. bisporus was good source for glutamic acid and phenyl alanine also it was rich in tryptophan, tyrosine, alanine and argenine. 
Table 6. Amino acids of yoghurt as affected either by the level of supplementing with Agaricus bisporus or the type of bacterial starter culture.

\begin{tabular}{|c|c|c|c|c|c|c|c|c|c|}
\hline \multirow{3}{*}{$\begin{array}{l}\text { Amino acid }(\mathrm{g} / 100 \mathrm{ml}) \\
\text { Essential Amino Acids: }\end{array}$} & \multicolumn{9}{|c|}{ level of supplementing with mushroom } \\
\hline & \multicolumn{3}{|c|}{$0.0 \%$ (control) } & \multicolumn{3}{|c|}{$5 \%$} & \multicolumn{3}{|c|}{$10 \%$} \\
\hline & YC & $\mathrm{YL}$ & YB & YC & $\mathrm{YL}$ & YB & YC & YL & YB \\
\hline Isoleucine & $0.1823^{\mathrm{c}, \mathrm{a}}$ & $0.1823^{\mathrm{b}, \mathrm{a}}$ & $0.1823^{\mathrm{a}, \mathrm{a}}$ & $0.1827^{\mathrm{c}, \mathrm{a}}$ & $0.1827^{b, a}$ & $0.1827^{\mathrm{a}, \mathrm{a}}$ & $0.1831^{\mathrm{c}, \mathrm{a}}$ & $0.1831^{\mathrm{b}, \mathrm{a}}$ & $0.1831^{\mathrm{a}, \mathrm{a}}$ \\
\hline Leucine & $0.3177^{\mathrm{a}, \mathrm{b}}$ & $0.3176^{b, b}$ & $0.3177^{c, a}$ & $0.3111^{\mathrm{a}, \mathrm{b}}$ & $0.3111^{\mathrm{b}, \mathrm{b}}$ & $0.3111^{c, a}$ & $0.3046^{\mathrm{a}, \mathrm{b}}$ & $0.3046^{\mathrm{b}, \mathrm{b}}$ & $0.3046^{c, a}$ \\
\hline Lysine & $0.2723^{c, a}$ & $0.2723^{b, a}$ & $0.2723^{a, b}$ & $0.2738^{c, a}$ & $0.2738^{\mathrm{b}, \mathrm{a}}$ & $0.2738^{\mathrm{a}, \mathrm{b}}$ & $0.2754^{c, a}$ & $0.2754^{\mathrm{b}, \mathrm{a}}$ & $0.2754^{\mathrm{a}, \mathrm{b}}$ \\
\hline Tryptophan & $0.0020^{c, a}$ & $0.0021^{b, a}$ & $0.0021^{a, b}$ & $0.2159^{c, a}$ & $0.2159^{\mathrm{b}, \mathrm{a}}$ & $0.2158^{\mathrm{a}, \mathrm{b}}$ & $0.4297^{c, a}$ & $0.4298^{\mathrm{b}, \mathrm{a}}$ & $0.4298^{\mathrm{a}, \mathrm{b}}$ \\
\hline Therionine & $0.1550^{\mathrm{a}, \mathrm{a}}$ & $0.1549^{b, a}$ & $0.1550^{c, a}$ & $0.1542^{\mathrm{a}, \mathrm{a}}$ & $0.1542^{b, a}$ & $0.1542^{c, a}$ & $0.1536^{\mathrm{a}, \mathrm{a}}$ & $0.1536^{\mathrm{b}, \mathrm{a}}$ & $0.1536^{c, a}$ \\
\hline Valine & $0.2150^{\mathrm{a}, \mathrm{b}}$ & $0.2150^{b, b}$ & $0.2150^{c, a}$ & $0.2078^{\mathrm{a}, \mathrm{b}}$ & $0.2078^{\mathrm{b}, \mathrm{b}}$ & $0.2078^{c, a}$ & $0.2006^{a, b}$ & $0.2006^{\mathrm{b}, \mathrm{b}}$ & $0.2006^{c, a}$ \\
\hline Methionine & $0.1488^{a, b}$ & $0.1488^{b, b}$ & $0.1488^{c, a}$ & $0.1436^{\mathrm{a}, \mathrm{b}}$ & $0.1436^{\mathrm{b}, \mathrm{b}}$ & $0.1436^{c, a}$ & $0.1385^{a, b}$ & $0.1385^{b, b}$ & $0.1385^{c, a}$ \\
\hline Cesteine & $0.0260^{c, a}$ & $0.0261^{b, a}$ & $0.0261^{\mathrm{a,b}}$ & $0.0286^{\mathrm{c}, \mathrm{a}}$ & $0.0286^{\mathrm{b}, \mathrm{a}}$ & $0.0286^{a, b}$ & $0.0312^{c, a}$ & $0.0312^{b, a}$ & $0.0312^{\mathrm{a}, \mathrm{b}}$ \\
\hline Phenylalanine & $0.1607^{c, a}$ & $0.1607^{\mathrm{b}, \mathrm{a}}$ & $0.1607^{\mathrm{a}, \mathrm{a}}$ & $0.1620^{c, a}$ & $0.1620^{b, a}$ & $0.1620^{\mathrm{a}, \mathrm{a}}$ & $0.1633^{\mathrm{c}, \mathrm{a}}$ & $0.1633^{\mathrm{b}, \mathrm{a}}$ & $0.1633^{a, a}$ \\
\hline Tyrosine & $0.0949^{c, a}$ & $0.0948^{\mathrm{b}, \mathrm{a}}$ & $0.0948^{\mathrm{a}, \mathrm{b}}$ & $0.1453^{c, a}$ & $0.1453^{\mathrm{b}, \mathrm{a}}$ & $0.1453^{\mathrm{a}, \mathrm{b}}$ & $0.1463^{\mathrm{c,a}}$ & $0.1463^{b, a}$ & $0.1463^{\mathrm{a}, \mathrm{b}}$ \\
\hline Total EAA & $1.5747^{\mathrm{c}, \mathrm{a}}$ & $1.5746^{\mathrm{b}, \mathrm{a}}$ & $1.5748^{\mathrm{a}, \mathrm{b}}$ & $1.8260^{\mathrm{c}, \mathrm{a}}$ & $1.8260^{\mathrm{b}, \mathrm{a}}$ & $1.8259^{\mathrm{a}, \mathrm{b}}$ & $2.0253^{c, a}$ & $2.0254^{b, a}$ & $2.0254^{\mathrm{a}, \mathrm{b}}$ \\
\hline \multicolumn{10}{|l|}{ Non-Essential Amino acids: } \\
\hline Aspartic acid & $0.2656^{\mathrm{a}, \mathrm{b}}$ & $0.2656^{\mathrm{b}, \mathrm{b}}$ & $0.2656^{c, a}$ & $0.2622^{\mathrm{a}, \mathrm{b}}$ & $0.2622^{\mathrm{b}, \mathrm{b}}$ & $0.2622^{c, a}$ & $0.2588^{\mathrm{a}, \mathrm{b}}$ & $0.2588^{\mathrm{b}, \mathrm{b}}$ & $0.2588^{c, a}$ \\
\hline Glutamic acid & $0.0673^{c, a}$ & $0.0673^{b, a}$ & $0.0673^{\mathrm{a}, \mathrm{b}}$ & $0.0768^{c, a}$ & $0.0768^{\mathrm{b}, \mathrm{a}}$ & $0.0768^{\mathrm{a}, \mathrm{b}}$ & $0.0890^{c, a}$ & $0.0890^{\mathrm{b}, \mathrm{a}}$ & $0.0890^{\mathrm{a}, \mathrm{b}}$ \\
\hline Serine & $0.2009^{a, b}$ & $0.2009^{b, b}$ & $0.2009^{c, a}$ & $0.1995^{\mathrm{a}, \mathrm{b}}$ & $0.1995^{\mathrm{b}, \mathrm{b}}$ & $0.1995^{c, a}$ & $0.1981^{a, b}$ & $0.1981^{b, b}$ & $0.1981^{c, a}$ \\
\hline Glycine & $0.0672^{c, a}$ & $0.0672^{b, a}$ & $0.0672^{\mathrm{a}, \mathrm{b}}$ & $0.0717^{c, a}$ & $0.0717^{\mathrm{b}, \mathrm{a}}$ & $0.0717^{\mathrm{a}, \mathrm{b}}$ & $0.0790^{c, a}$ & $0.0790^{b, a}$ & $0.0790^{a, b}$ \\
\hline Argenine & $0.0967^{c, a}$ & $0.0967^{b, a}$ & $0.0967^{a, b}$ & $0.1028^{c, a}$ & $0.1028^{\mathrm{b}, \mathrm{a}}$ & $0.1028^{a, b}$ & $0.1078^{\mathrm{c}, \mathrm{a}}$ & $0.1078^{\mathrm{b}, \mathrm{a}}$ & $0.1078^{a, b}$ \\
\hline Alanine & $0.1079^{c, a}$ & $0.1079^{b, a}$ & $0.1079^{a, b}$ & $0.1152^{c, a}$ & $0.1152^{b, a}$ & $0.1152^{a, b}$ & $0.1225^{c, a}$ & $0.1225^{b, a}$ & $0.1225^{\mathrm{a}, \mathrm{b}}$ \\
\hline Proline & $0.3794^{a, b}$ & $0.3795^{b, b}$ & $0.3795^{c, a}$ & $0.3707^{a, b}$ & $0.3707^{b, b}$ & $0.3707^{c, a}$ & $0.3611^{a, b}$ & $0.3611^{b, b}$ & $0.3611^{c, a}$ \\
\hline Histidine & $0.0915^{\mathrm{a}, \mathrm{b}}$ & $0.0914^{\mathrm{b}, \mathrm{b}}$ & $0.0914^{c, a}$ & $0.0898^{\mathrm{a}, \mathrm{b}}$ & $0.0898^{\mathrm{b}, \mathrm{b}}$ & $0.0898^{c, a}$ & $0.0881^{a, b}$ & $0.0881^{b, b}$ & $0.0881^{c, a}$ \\
\hline Total non EAA & $1.2765^{\mathrm{c}, \mathrm{a}}$ & $1.2765^{\mathrm{b}, \mathrm{a}}$ & $1.2765^{\mathrm{a}, \mathrm{b}}$ & $1.2937^{\mathrm{c}, \mathrm{a}}$ & $1.2937^{\mathrm{b}, \mathrm{a}}$ & $1.2937^{\mathrm{a}, \mathrm{b}}$ & $1.3044^{\mathrm{c}, \mathrm{a}}$ & $1.3044^{\mathrm{b}, \mathrm{a}}$ & $1.3044^{\mathrm{a}, \mathrm{b}}$ \\
\hline Total A.A & $2.8512^{\mathrm{c}, \mathrm{a}}$ & $2.8511^{b, a}$ & $2.8513^{a, b}$ & $3.1197^{\mathrm{c}, \mathrm{a}}$ & $3.1197^{b, a}$ & $3.1196^{a, b}$ & $3.3297^{c, a}$ & $3.3298^{\mathrm{b}, \mathrm{a}}$ & $3.3298^{\mathrm{a}, \mathrm{b}}$ \\
\hline
\end{tabular}

The letters before comma possess the factor of mushroom level. While those after comma possess the factor of the starter. The means with the same letter at any position were not

significant $(P>0.05)$ 


\section{Minerals and Vitamins contents}

Regarding the minerals and vitamins contents of yoghurt, data given in table (7) stated that neither the kind of starter nor the level of supplementing $A$. bisporus led to any significant differences ( $P>0.05$ ) in the minerals and vitamins contents of yoghurt.

Data presented in table (7) showed that adding A. bisporus caused significant $(\mathrm{P}<0.005)$ decrease in calcium and sodium ofyoghurt fortified with levels of $A$. bisporus comparing with the control, whilemagneium, potassium, iron, phosphorus, manganese and copper were significantly higher than the control as reported by. Verma et al.,(1987).

Regarding the zinc content of yoghurt, data given in table (7) showed no significant differences in all treatments as affected by the level supplementing or the bacterial culture.

Also the addition of $A$. bisporus led to increase vitamins content (riboflavin, niacin, B12, biotin, folate and thiamin). While the kind of starter culture had no significant differences.

Furthermore, the yoghurt fortified with levels of $A$. bisporus was rich in biotin, folate and niacin comparing with the control( $0.0 \%)$.

\section{Cholesterol Content:}

It was clear from Table (8) which revealed significant variations between the two levels of supplementing $A$. bisporus and the starter culture during the storage period. The cultures $Y C, Y L$ and $Y B$ were able to assimilate cholesterol during storage, but the reduction of cholesterol in the treatments inculated with $Y L$ culture was the highest comparing with $Y C$ and $Y B$ cultures throughout the storage period. Types of fermented milk the level of supplementing $A$. bisporus had the highest percent of cholesterol reduction compared to standardized buffalo's milk ( $4 \%$ fat). This could be due to that $A$. bisporusis an ideal food for the dietetic prevention of atherosclerosis due to their high fiber and low fat content. The edible mushrooms in a natural hypocholesterolemic and antisclerotic diet is often prescribed in Oriental medicine (Sun et al., 1984). 
Table 7. Minerals and Vitamins contents of yoghurt as affected either by the level of supplementing with Agaricus bisporus or the type of bacterial starter culture (mg/ 100g yoghurt).

\begin{tabular}{|c|c|c|c|c|c|c|c|c|c|}
\hline \multirow{3}{*}{ Minerals (mg) } & \multicolumn{9}{|c|}{ level of supplementing with mushroom } \\
\hline & \multicolumn{3}{|c|}{$0.0 \%$ (control) } & \multicolumn{3}{|c|}{$5 \%$} & \multicolumn{3}{|c|}{$10 \%$} \\
\hline & YC & $\mathrm{YL}$ & YB & YC & $\mathrm{YL}$ & YB & YC & $\mathrm{YL}$ & YB \\
\hline $\mathrm{Mg}$ & $15^{c, b}$ & $15.1^{c, a}$ & $15.0^{c, a}$ & $15.337^{\mathrm{b}, \mathrm{b}}$ & $15.338^{\mathrm{b}, \mathrm{a}}$ & $15.338^{\mathrm{b}, \mathrm{a}}$ & $15.676^{a, a}$ & $15.676^{\mathrm{a}, \mathrm{a}}$ & $15.675^{a, b}$ \\
\hline $\mathrm{Na}$ & $51.0^{\mathrm{a}, \mathrm{b}}$ & $51.0^{\mathrm{a}, \mathrm{b}}$ & $51.02^{\mathrm{a}, \mathrm{a}}$ & $48.523^{\mathrm{b}, \mathrm{b}}$ & $48.533^{\mathrm{b}, \mathrm{b}}$ & $48.527^{\mathrm{b}, \mathrm{a}}$ & $46.046^{c, b}$ & $46.048^{c, b}$ & $46.046^{c, a}$ \\
\hline $\mathrm{K}$ & $116^{\mathrm{c}, \mathrm{a}}$ & $116.2^{\mathrm{c}, \mathrm{a}}$ & $116.11^{\mathrm{c}, \mathrm{b}}$ & $132.905^{\mathrm{b}, \mathrm{a}}$ & $132.906^{\mathrm{b}, \mathrm{a}}$ & $132.905^{\mathrm{b}, \mathrm{b}}$ & $149.81^{\mathrm{a}, \mathrm{a}}$ & $149.81^{\mathrm{a}, \mathrm{a}}$ & $149.80^{\mathrm{a}, \mathrm{b}}$ \\
\hline $\mathrm{Fe}$ & $0.30^{\mathrm{c}, \mathrm{ba}}$ & $0.32^{\mathrm{c}, \mathrm{a}}$ & $0.31^{\mathrm{c}, \mathrm{b}}$ & $0.3539^{\mathrm{b}, \mathrm{ba}}$ & $0.3538^{\mathrm{b}, \mathrm{a}}$ & $0.3539^{\mathrm{b}, \mathrm{b}}$ & $0.4078^{\mathrm{a}, \mathrm{ba}}$ & $0.4079^{\mathrm{a}, \mathrm{a}}$ & $0.4078^{\mathrm{a}, \mathrm{b}}$ \\
\hline $\mathrm{Ca}$ & $195.0^{\mathrm{a}, \mathrm{c}}$ & $195.1^{\mathrm{a}, \mathrm{b}}$ & $195.0^{\mathrm{a}, \mathrm{a}}$ & $185.404^{\mathrm{b}, \mathrm{c}}$ & $185.500^{\mathrm{b}, \mathrm{b}}$ & $185.405^{\mathrm{b}, \mathrm{a}}$ & $175.806^{c, c}$ & $175.901^{\mathrm{c}, \mathrm{b}}$ & $175.809^{c, a}$ \\
\hline $\mathrm{Zn}$ & $0.700^{\mathrm{a}, \mathrm{a}}$ & $0.701^{\mathrm{a}, \mathrm{a}}$ & $0.700^{\mathrm{a}, \mathrm{a}}$ & $0.706^{\mathrm{a}, \mathrm{a}}$ & $0.708^{\mathrm{a}, \mathrm{a}}$ & $0.707^{\mathrm{a}, \mathrm{a}}$ & $0.712^{\mathrm{a}, \mathrm{a}}$ & $0.712^{\mathrm{a}, \mathrm{a}}$ & $0.713^{\mathrm{a}, \mathrm{a}}$ \\
\hline $\mathrm{P}$ & $191.00^{c, a}$ & $191.10^{\mathrm{c}, \mathrm{a}}$ & $191.00^{c, b}$ & $236.80^{\mathrm{b}, \mathrm{a}}$ & $236.70^{\mathrm{b}, \mathrm{a}}$ & $236.70^{\mathrm{b}, \mathrm{b}}$ & $282.60^{\mathrm{a}, \mathrm{a}}$ & $282.63^{\mathrm{a}, \mathrm{a}}$ & $282.63^{\mathrm{a}, \mathrm{b}}$ \\
\hline $\mathrm{Cu}$ & - & - & - & $0.0190^{\mathrm{b}, \mathrm{a}}$ & $0.0190^{\mathrm{b}, \mathrm{a}}$ & $0.0190^{\mathrm{b}, \mathrm{b}}$ & $0.0381^{\mathrm{a}, \mathrm{a}}$ & $0.0382^{\mathrm{a}, \mathrm{a}}$ & $0.0382^{\mathrm{a}, \mathrm{b}}$ \\
\hline $\mathrm{Mn}$ & - & - & - & $0.0128^{\mathrm{b}, \mathrm{a}}$ & $0.0128^{\mathrm{b}, \mathrm{a}}$ & $0.0128^{\mathrm{b}, \mathrm{b}}$ & $0.0256^{\mathrm{a}, \mathrm{a}}$ & $0.0257^{\mathrm{a}, \mathrm{a}}$ & $0.0256^{\mathrm{a}, \mathrm{b}}$ \\
\hline \multicolumn{10}{|l|}{$\begin{array}{l}\text { Vitamins } \\
\text { (mg) }\end{array}$} \\
\hline Riboflavin(B) & $0.1100^{c, a}$ & $0.1101^{c, a}$ & $0.1100^{c, a}$ & $0.3346^{\mathrm{b}, \mathrm{a}}$ & $0.3345^{\mathrm{b}, \mathrm{b}}$ & $0.3345^{\mathrm{b}, \mathrm{b}}$ & $0.5590^{\mathrm{a}, \mathrm{b}}$ & $0.5590^{\mathrm{a}, \mathrm{b}}$ & $0.5591^{\mathrm{a}, \mathrm{a}}$ \\
\hline Niacin & $0.1700^{c, a}$ & $0.1700^{c, a}$ & $0.1700^{c, a}$ & $2.8615^{\mathrm{b}, \mathrm{a}}$ & $2.8615^{\mathrm{b}, \mathrm{a}}$ & $2.8615^{\mathrm{b}, \mathrm{a}}$ & $5.5530^{\mathrm{a}, \mathrm{a}}$ & $5.5530^{\mathrm{a}, \mathrm{a}}$ & $5.5530^{\mathrm{a}, \mathrm{a}}$ \\
\hline$B_{12}(\mu g)$ & $0.4001^{c, a}$ & $0.4002^{\mathrm{b}, \mathrm{a}}$ & $0.4002^{\mathrm{a}, \mathrm{b}}$ & $0.4200^{c, a}$ & $0.4201^{\mathrm{b}, \mathrm{a}}$ & $0.4201^{\mathrm{a}, \mathrm{b}}$ & $0.4400^{c, a}$ & $0.4400^{\mathrm{b}, \mathrm{a}}$ & $0.4400^{\mathrm{a}, \mathrm{b}}$ \\
\hline Biotin & $0.0170^{c, b}$ & $0.0171^{c, a}$ & $0.0171^{c^{c a}}$ & $8.5123^{\mathrm{b}, \mathrm{a}}$ & $8.5123^{\mathrm{b}, \mathrm{a}}$ & $8.5123^{\mathrm{b}, \mathrm{a}}$ & $17.0117^{\mathrm{a}, \mathrm{a}}$ & $17.0117^{\mathrm{a}, \mathrm{a}}$ & $17.0117^{\mathrm{a}, \mathrm{a}}$ \\
\hline Folate $(\mu \mathrm{g})$ & $0.6001^{c, a}$ & $0.6000^{c, b}$ & $0.6000^{c, b}$ & $36.5700^{\mathrm{b}, \mathrm{a}}$ & $36.5700^{\mathrm{b}, \mathrm{a}}$ & $36.5700^{\text {b.a }}$ & $72.5400^{\mathrm{a}, \mathrm{a}}$ & $72.5400^{\mathrm{a}, \mathrm{a}}$ & $72.5400^{\mathrm{a}, \mathrm{a}}$ \\
\hline Thiamin $\left(B_{1}\right)$ & $0.0500^{c . b}$ & $0.0501^{c, a}$ & $0.0501^{c^{c a}}$ & $0.0875^{\mathrm{b}, \mathrm{a}}$ & $0.0875^{\mathrm{b}, \mathrm{a}}$ & $0.0875^{\mathrm{b}, \mathrm{a}}$ & $0.1250^{a, a}$ & $0.1250^{\mathrm{a}, \mathrm{a}}$ & $0.12500^{\mathrm{a}, \mathrm{a}}$ \\
\hline
\end{tabular}

The letters before comma possess the factor of mushroom level. While those after comma possess the factor of the starter. The means with the same letter at any position were not significantly different $(P>0.05)$ 


\section{Rheological analysis}

Regarding curd tension for all yoghurt treatments with different levels of $A$. bisporus (during storage periods), it was noticed that $A$. bisporus adding with different levels had an effect on the curd tension (fig 2). The highest curd tension values were obtained in fortified yoghurt with A. bisporus (10\%), followed by A. bisporus (5\%) and $A$. bisporus (0.0\%).

Data illustrated too in fig.(2) showed that the different kinds used of bacterial starter cultures affected the curd tentionat the beginning and the end of cold storage period.Yoghurt with YL starter had the highest curd tension.

Generally It is obviously clear that synercis and curd tension of yoghurt were significantly affected by fortification with different levels of $A$. bisporus and different types of biological starter cultures. That was occurred during storage periods of yoghurt, also the curd tension significantly increased with increasing thestorage period.

The viscosity values of functional yoghurt fortified with levels of $A$. bisporus and used different kinds of biological starter cultures were stated and illustrated in Fig (3). The data indicated that the treatment of $\mathrm{YC}$ and $10 \% A$. bisporus had higher viscosity value than that in treatments fortified with $5 \% A$. bisporusor control. For example the viscosity value was 410,411 and $408 \mathrm{cp}$ for $\mathrm{YC}, \mathrm{YL}$ and $\mathrm{YC}, \mathrm{YL}$ and $\mathrm{YB}$ control treatments while were 529,530, 528 in treatments with $5 \%$ of $A$. bisporus in order. The corresponding values in treatments with $10 \%$ A. bisporus were 691,693 and $690 \mathrm{cp}$ in same order. The obtained data also indicated that the viscosity was highier in treatments with YL than others (YC,YB). That could be due to that DF had desirable functional properties, such as providing texture, gelling, thickening, emulsification, and stabilization in DF-enriched foods (Nelson, 2001).

Therefore, DF research, particularly in the growing nutraceutical industry, has gained a lot of attention recently (Jalili et al., 2000). The results also showed that increasing the ratio added of $A$. bisporus caused significant increase in viscosity. That increasing was significant with increasing the storage period.

Furthermore, the rheological parameters of all yoghurt treatments raised as a function of cold storage period for 3 weeks. That might be due to the acidity developed as the cold storage period prolonged. Those observations agreed with those reported by Husein et al. (2006). 


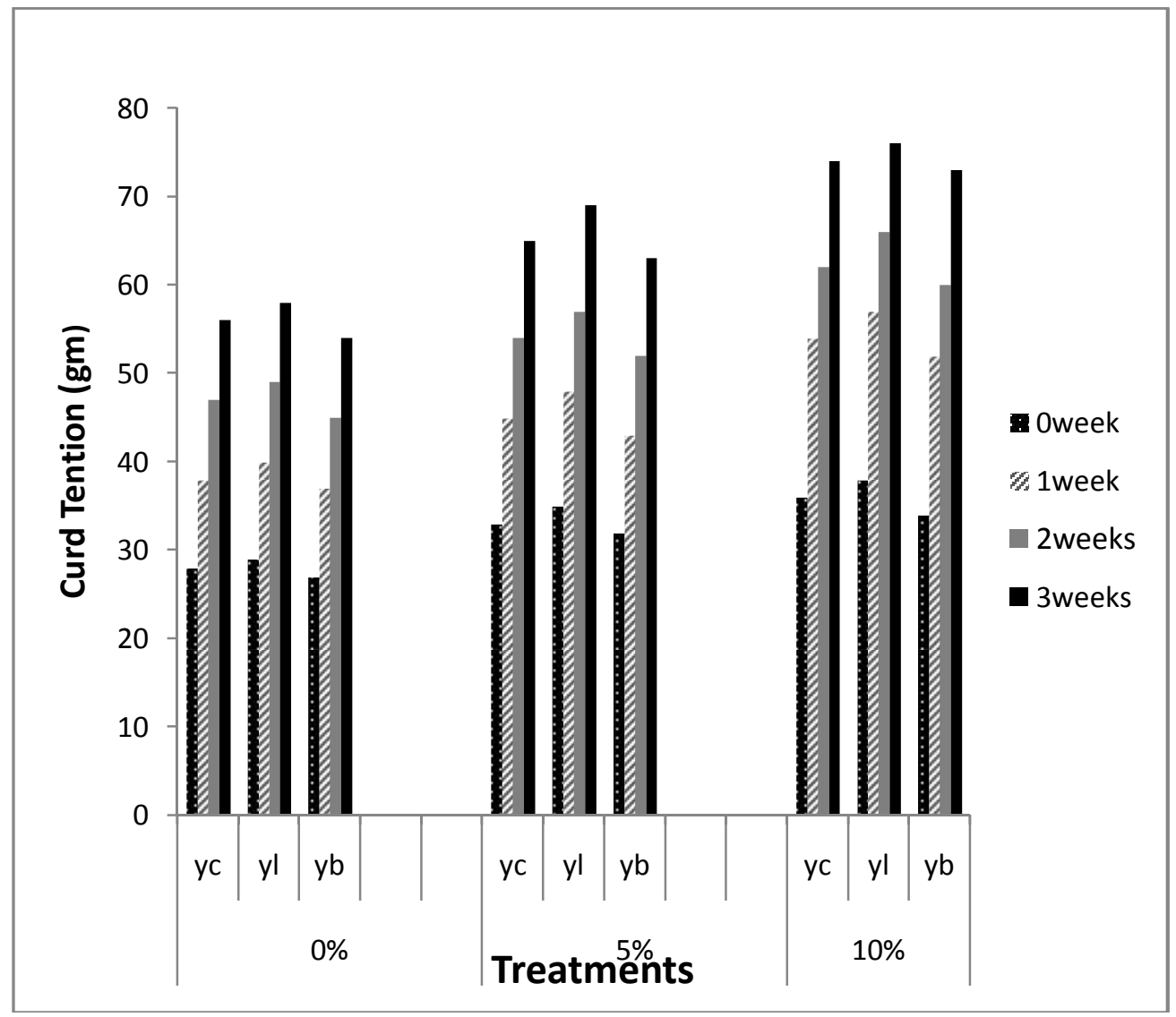

Fig. 2. curd tension (gm) of yoghurt as affected either by the level of supplementing Agaricus bisporus or the type of bacterial starter culture.

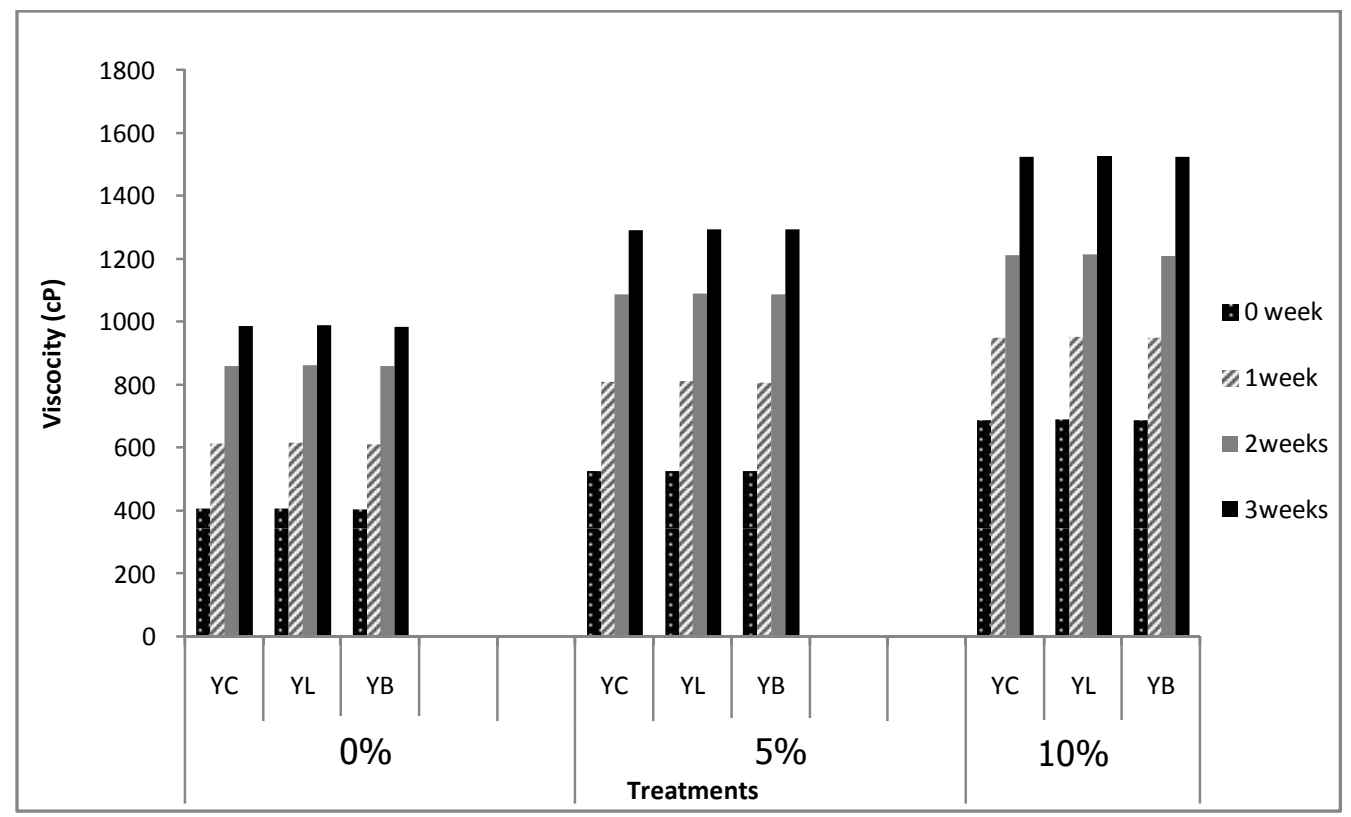

Fig. 3. Viscosity (cp) of yoghurt as affected either by the level of supplementing mushroom or the type of bacterial starter culture. 
Table 8. Cholesterol content $(\mathrm{mg} / 100 \mathrm{~g})$ of yoghurt as affected either by the level of supplementing with Agaricus bisporus or the type of bacterial starter culture during storage period.

\begin{tabular}{|c|c|c|c|c|c|c|c|c|c|c|c|c|c|c|c|c|c|c|}
\hline \multirow{4}{*}{$\begin{array}{l}\text { Cold } \\
\text { storage } \\
\text { period } \\
\text { (week) }\end{array}$} & \multicolumn{18}{|c|}{ level of supplementing with mushroom } \\
\hline & \multicolumn{6}{|c|}{$0 \%$} & \multicolumn{6}{|c|}{$5 \%$} & \multicolumn{6}{|c|}{$10 \%$} \\
\hline & \multicolumn{2}{|c|}{ YC } & \multicolumn{2}{|c|}{ YL } & \multicolumn{2}{|c|}{ YB } & \multicolumn{2}{|c|}{ YC } & \multicolumn{2}{|c|}{ YL } & \multicolumn{2}{|c|}{ YB } & \multicolumn{2}{|c|}{ YC } & \multicolumn{2}{|c|}{$\mathrm{YL}$} & \multicolumn{2}{|c|}{ YB } \\
\hline & T. C $^{*}$ & Red.* & T. . ${ }^{*}$ & Red. ${ }^{*}$ & T.C. & Red. $^{*}$ & T.C ${ }^{*}$ & Red. $^{*}$ & T. . ${ }^{*}$ & Red. $^{*}$ & T. . ${ }^{*}$ & Red.* & T.C. & Red.* & T. . $C^{*}$ & Red.* & T.C. & Red. $^{*}$ \\
\hline 0 & $17.21^{a, b, d}$ & $22.19^{c, c, c}$ & $16.35^{b, c . d}$ & $26.08^{b, a, c c}$ & $16.78^{c, a, d}$ & $24.14^{\mathrm{a}, \mathrm{b}, \mathrm{c}}$ & $15.52^{\mathrm{a}, \mathrm{b}, \mathrm{d}}$ & $29.83^{c, c, c}$ & $14.45^{\mathrm{b}, c, \mathrm{~d}}$ & $34.67^{\mathrm{b}, \mathrm{a}, \mathrm{a}}$ & $15.01^{c, a, d}$ & $32.14^{a, b, c}$ & $13.70^{b, \mathrm{~d} d}$ & $37.92^{c, c, c}$ & $12.37^{b, c, d}$ & $44.07^{\mathrm{b}, \mathrm{a}, \mathrm{c}}$ & $13.05^{c, a, d}$ & $41.00^{\mathrm{a}, \mathrm{b}, \mathrm{c}}$ \\
\hline 1 & $16.85^{\mathrm{a}, \mathrm{b}, \mathrm{a}}$ & $23.82^{c, c, b}$ & $15.90^{b, c, a}$ & $28.11^{b, a, b}$ & $16.36^{c, a, a}$ & $26.03^{\mathrm{a}, \mathrm{b}, \mathrm{b}}$ & $15.22^{\mathrm{a}, \mathrm{b}, \mathrm{a}}$ & $31.19^{c, c, b}$ & $14.19^{b, c, a}$ & $35.84^{\mathrm{b}, \mathrm{a}, \mathrm{b}}$ & $14.76^{\mathrm{c}, \mathrm{a}, \mathrm{a}}$ & $33.27^{\mathrm{a}, \mathrm{b}, \mathrm{b}}$ & $13.45^{a, b, a}$ & $39.19^{c, c, b}$ & $12.24^{\mathrm{b}, \mathrm{c}, \mathrm{a}}$ & $44.66^{\mathrm{b}, \mathrm{a}, \mathrm{b}}$ & $12.90^{c, a, a}$ & $41.68^{a, b, b}$ \\
\hline 2 & $16.67^{\mathrm{a}, \mathrm{b}, \mathrm{b}}$ & $24.63^{c, c, b}$ & $15.72^{\mathrm{b}, \mathrm{c}, \mathrm{b}}$ & $28.93^{\mathrm{b}, \mathrm{a}, \mathrm{b}}$ & $16.14^{c, a, b}$ & $27.03^{\mathrm{a}, \mathrm{b}, \mathrm{b}}$ & $15.04^{a, b, b}$ & $32.00^{c, c, b}$ & $14.00^{b, c, b}$ & $36.70^{b, a, b}$ & $14.47^{\mathrm{c}, \mathrm{a}, \mathrm{b}}$ & $34.58^{\mathrm{a}, \mathrm{b}, \mathrm{b}}$ & $13.34^{a, b, b}$ & $39.69^{\mathrm{c}, \mathrm{c}, \mathrm{b}}$ & $12.15^{\mathrm{b}, \mathrm{c}, \mathrm{b}}$ & $45.07^{\mathrm{b}, \mathrm{a}, \mathrm{b}}$ & $12.75^{\mathrm{c}, \mathrm{a}, \mathrm{b}}$ & $42.35^{a, b, b}$ \\
\hline 3 & $16.63^{\mathrm{a}, \mathrm{a}, \mathrm{c}}$ & $25.27^{c, c, a}$ & $15.54^{b . c, c}$ & $29.74^{\mathrm{b}, \mathrm{a}, \mathrm{a}}$ & $15.98^{\mathrm{c}, \mathrm{a}, \mathrm{c}}$ & $27.75^{\mathrm{a}, \mathrm{b}, \mathrm{a}}$ & $14.95^{\mathrm{a}, \mathrm{b}, \mathrm{c}}$ & $32.41^{c, c, a}$ & $13.85^{\mathrm{b}, \mathrm{c}, \mathrm{c}}$ & $37.38^{\mathrm{b}, \mathrm{a}, \mathrm{a}}$ & $14.28^{c, a, c}$ & $35.44^{\mathrm{a}, \mathrm{b}, \mathrm{a}}$ & $13.21^{1, \mathrm{a}, \mathrm{c}, \mathrm{c}}$ & $40.28^{\mathrm{c}, \mathrm{c}, \mathrm{a}}$ & $12.05^{b, c, c}$ & $45.52^{\mathrm{b}, \mathrm{a}, \mathrm{a}}$ & $12.55^{c, a, c}$ & $43.26^{\mathrm{a}, \mathrm{b}, \mathrm{a}}$ \\
\hline
\end{tabular}

*T.C: Total cholesterol. $\mathrm{Mg} / 100 \mathrm{~g}$ yoghurt

*Red: Reduction cholesterol. \%

The letters before comma possess the factor of mushroom level. While those after comma possess the factor of the starter and storage period,

respectively. The means with the same letter at any position were not significantly different $(P>0.05)$ 


\section{Sensory evaluation}

Table (9) showed the judging scores and its statistical analysis of yoghurt during cold storage period as affected either by the level of supplementing with $A$. bisporus and/or the type of bacterial starter culture used. Regarding the appearance score, body and texture, given in Table (9) exhibited no differences among all yoghurt treatments whether fortified with A. bisporus or not (the control) and/or culture with YC, YL and YB as well as when fresh or along cold storage period.

Table 9. Organoleptic score of yoghurt as affected either by the level of supplementing with Agaricus bisporus or the type of bacterial starter culture during storage period.

\begin{tabular}{|c|c|c|c|c|c|c|c|c|c|}
\hline \multirow{3}{*}{$\begin{array}{c}\text { Cold } \\
\text { storage } \\
\text { period } \\
\text { (week) }\end{array}$} & \multicolumn{9}{|c|}{ level of supplementing mushroom } \\
\hline & \multicolumn{3}{|c|}{$0.0 \%$ (control) } & \multicolumn{3}{|c|}{$5 \%$} & \multicolumn{3}{|c|}{$10 \%$} \\
\hline & YC & YL & YB & YC & YL & YB & YC & $\mathrm{YL}$ & YB \\
\hline \multicolumn{10}{|c|}{ Appearance score (5 points) } \\
\hline 0 & $5^{\mathrm{a}, \mathrm{a}, \mathrm{a}}$ & $5^{a, a, a}$ & $5^{\mathrm{a}, \mathrm{a}, \mathrm{a}}$ & $5^{a, a, a}$ & $5^{\mathrm{a}, \mathrm{a}, \mathrm{a}}$ & $5^{\mathrm{a}, \mathrm{a}, \mathrm{a}}$ & $5^{\mathrm{a}, \mathrm{a}, \mathrm{a}}$ & $5^{\mathrm{a}, \mathrm{a}, \mathrm{a}}$ & $5^{a, a, a}$ \\
\hline 1 & $5^{\mathrm{a}, \mathrm{a}, \mathrm{a}}$ & $5^{a, a, a}$ & $5^{\mathrm{a}, \mathrm{a}, \mathrm{a}}$ & $5^{a, a, a}$ & $5^{\mathrm{a}, \mathrm{a}, \mathrm{a}}$ & $5^{\mathrm{a}, \mathrm{a}, \mathrm{a}}$ & $5^{\mathrm{a}, \mathrm{a}, \mathrm{a}}$ & $5^{\mathrm{a}, \mathrm{a}, \mathrm{a}}$ & $5^{a, a, a}$ \\
\hline 2 & $5^{\mathrm{a}, \mathrm{a}, \mathrm{a}}$ & $5^{a, a, a}$ & $5^{\mathrm{a}, \mathrm{a}, \mathrm{a}}$ & $5^{a, a, a}$ & $5^{\mathrm{a}, \mathrm{a}, \mathrm{a}}$ & $5^{\mathrm{a}, \mathrm{a}, \mathrm{a}}$ & $4^{\mathrm{a}, \mathrm{a}, \mathrm{a}}$ & $4^{\mathrm{a}, \mathrm{a}, \mathrm{a}}$ & $4^{a, a, a}$ \\
\hline 3 & $5^{a, a, a}$ & $5^{a, a, a}$ & $5^{a, a, a}$ & $5^{a, a, a}$ & $5^{\mathrm{a}, \mathrm{a}, \mathrm{a}}$ & $5^{\mathrm{a}, \mathrm{a}, \mathrm{a}}$ & $4^{\mathrm{a}, \mathrm{a}, \mathrm{a}}$ & $4^{\mathrm{a}, \mathrm{a}, \mathrm{a}}$ & $4^{a, a, a}$ \\
\hline \multicolumn{10}{|c|}{ Body and texture score (5 points) } \\
\hline 0 & $5^{\mathrm{a}, \mathrm{a}, \mathrm{a}}$ & $5^{a, a, a}$ & $5^{\mathrm{a}, \mathrm{a}, \mathrm{a}}$ & $5^{a, a, a}$ & $5^{\mathrm{a}, \mathrm{a}, \mathrm{a}}$ & $5^{\mathrm{a}, \mathrm{a}, \mathrm{a}}$ & $5^{\mathrm{a}, \mathrm{a}, \mathrm{a}}$ & $5^{\mathrm{a}, \mathrm{a}, \mathrm{a}}$ & $5^{a, a, a}$ \\
\hline 1 & $5^{a, a, a}$ & $5^{a, a, a}$ & $5^{\mathrm{a}, \mathrm{a}, \mathrm{a}}$ & $5^{a, a, a}$ & $5^{\mathrm{a}, \mathrm{a}, \mathrm{a}}$ & $5^{\mathrm{a}, \mathrm{a}, \mathrm{a}}$ & $5^{\mathrm{a}, \mathrm{a}, \mathrm{a}}$ & $5^{\mathrm{a}, \mathrm{a}, \mathrm{a}}$ & $5^{a, a, a}$ \\
\hline 2 & $5^{a, a, a}$ & $5^{a, a, a}$ & $5^{\mathrm{a}, \mathrm{a}, \mathrm{a}}$ & $5^{a, a, a}$ & $5^{\mathrm{a}, \mathrm{a}, \mathrm{a}}$ & $5^{a, a, a}$ & $5^{a, a, a}$ & $5^{\mathrm{a}, \mathrm{a}, \mathrm{a}}$ & $5^{a, a, a}$ \\
\hline 3 & $4^{a, a, a}$ & $4^{a, a, a}$ & $4^{a, a, a}$ & $5^{a, a, a}$ & $5^{\mathrm{a}, \mathrm{a}, \mathrm{a}}$ & $5^{\mathrm{a}, \mathrm{a}, \mathrm{a}}$ & $5^{a, a, a}$ & $5^{a, a, a}$ & $5^{a, a, a}$ \\
\hline \multicolumn{10}{|c|}{ Flavor score (10 points) } \\
\hline 0 & $10^{\mathrm{a}, \mathrm{a}, \mathrm{a}}$ & $10^{\mathrm{a}, \mathrm{a}, \mathrm{a}}$ & $10^{\mathrm{a}, \mathrm{a}, \mathrm{a}}$ & $10^{\mathrm{a}, \mathrm{a}, \mathrm{a}}$ & $10^{\mathrm{a}, \mathrm{a}, \mathrm{a}}$ & $10^{\mathrm{a}, \mathrm{a}, \mathrm{a}}$ & $9^{b, a, a}$ & $9^{b, a, a}$ & $9^{b, a, a}$ \\
\hline 1 & $9^{a, a, a}$ & $9^{a, a, a}$ & $10^{\mathrm{a}, \mathrm{a}, \mathrm{a}}$ & $10^{\mathrm{a}, \mathrm{a}, \mathrm{a}}$ & $10^{\mathrm{a}, \mathrm{a}, \mathrm{a}}$ & $10^{a, a, a}$ & $9^{b, a, a}$ & $9^{b, a, a}$ & $9^{b, a, a}$ \\
\hline 2 & $8^{a, a, b}$ & $8^{a, a, b}$ & $9^{a, a, b}$ & $9^{a, a, b}$ & $9^{a, a, b}$ & $10^{a, a, b}$ & $8^{b, a, b}$ & $8^{b, a, b}$ & $9^{b, a, b}$ \\
\hline 3 & $8^{a, a, b}$ & $8^{a, a, b}$ & $9^{a, a, b}$ & $9^{a, a, b}$ & $8^{\mathrm{a}, \mathrm{a}, \mathrm{b}}$ & $9^{a, a, b}$ & $7^{b, a, b}$ & $7^{b, a, b}$ & $7^{\mathrm{b}, \mathrm{a}, \mathrm{b}}$ \\
\hline \multicolumn{10}{|c|}{ Total score (20 points) } \\
\hline 0 & $20^{\mathrm{b}, \mathrm{b}, \mathrm{a}}$ & $20^{b, b, a}$ & $20^{\mathrm{b}, \mathrm{a}, \mathrm{a}}$ & $20^{a, b, a}$ & $20^{a, b, a}$ & $20^{a, a, a}$ & $19^{c, b, a}$ & $19^{\mathrm{c}, \mathrm{b}, \mathrm{a}}$ & $19^{c, a, a}$ \\
\hline 1 & $19^{b, b, a}$ & $19^{b, b, a}$ & $20^{\mathrm{b}, \mathrm{a}, \mathrm{a}}$ & $20^{a, b, a}$ & $20^{a, b, a}$ & $20^{a, a, a}$ & $19^{c, b, a}$ & $19^{c, b, a}$ & $19^{\mathrm{c}, \mathrm{a}, \mathrm{a}}$ \\
\hline 2 & $18^{\mathrm{b}, \mathrm{b}, \mathrm{b}}$ & $18^{b, b, b}$ & $19^{\mathrm{b}, \mathrm{a}, \mathrm{b}}$ & $19^{a, b, b}$ & $19^{a, b, b}$ & $20^{a, a, b}$ & $17^{\mathrm{c}, \mathrm{b}, \mathrm{b}}$ & $17^{c, b, b}$ & $18^{\mathrm{c}, \mathrm{a}, \mathrm{b}}$ \\
\hline 3 & $17^{b, b, c}$ & $17^{b, b, c}$ & $18^{\mathrm{b}, \mathrm{a}, \mathrm{c}}$ & $19^{a, b, c}$ & $18^{a, b, c}$ & $19^{a, a, c}$ & $16^{c, b, c}$ & $16^{c, b, c}$ & $16^{c, a, c}$ \\
\hline
\end{tabular}

The letters before comma possess the factor of mushroom level. While those after comma possess the factor of the starter and storage period, respectively. The means with the same letter at any position were not significantly different $(P>0.05)$ 
Concerning the flavor score, the fortification with $A$. bisporus (5\%) was significantly higher than those of $A$. bisporus (10\%), regardless the kind of the starter. Nevertheless the control samples gained flavor scores higher than those yoghurt supplemented with $A$. bisporus at level $10 \%$ and the flavor scores of yoghurt was not significant influenced by the kind of starter. Moreover, with prolonging the cold storage period of yoghurt, the flavor score tended significantly to decrease $(p<0.001)$.

The total score of yoghurt which reflected the overall organoleptic quality of the product reveal that, the supplementation with $A$. bisporus at the level of $(5 \%)$ led to improve the total score versus the control.

Concerning the type of bacterial starter culture, the statistical analysis confirmed that the YB yoghurt gained significantly the highest total score compared with those made by using YC or YL starter culture.

Nevertheless, significant reduction in the total score was observed when the cold storage period exceeded more than one week. All samples were organoleptically accepted.

\section{Nutritional and daily values}

As could be noticed from the data in table (10), there were significant decreses in the energy of yoghurt associated with the proportional increase in the supplementing level with $A$. bisporus, regardless the kind of starter. Regarding the daily values $\%$ of the protein, total fat and total carbohydrate, data showed that, neither the kind of starter nor the level of supplementing with $A$. bisporus led to any significant differences ( $P>0.05)$ in the daily values $\%$ of the protein, total fat and total carbohydrates content of yoghurt.

Daily values (\%) of cholesterol decreased significantly as the supplementing level with $A$. bisporus increased. Because the high fiber contents in $A$. bisporus, caused significant increase in daily values\% of fiber.

Data presented in table (10) showed that adding $A$. bisporus caused significant decrease in the daily values\% of calcium and sodium comparing with the control, but magnesium, potassium, iron, zinc, phosphorus, manganese and copper was significantly higher than the control especially, the daily values\% of manganese and copper.

As appeared from table (10) the addition of $A$. bisporus led to increase all the daily values $\%$ of vitamins content measured riboflavin, niacin, B12,biotin,folate and thiamin. While the kind of starter culture did not give any significant differences in the daily values\%. 
Table 10. Daily values (DV\%) of nutrients in yoghurt as affected either by the level of supplementing with Agaricus bisporus or the type of bacterial starter culture.

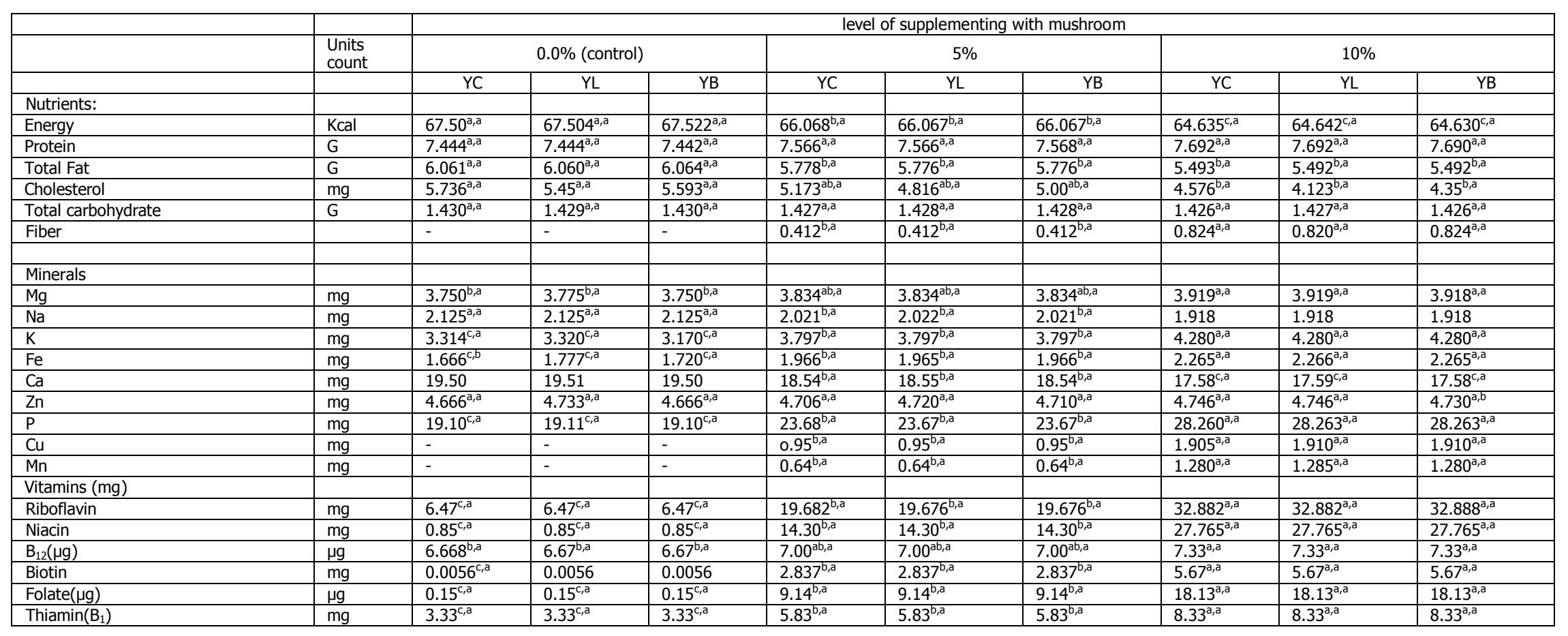

The letters before comma possess the factor of mushroom level. While those after comma possess the factor of the starter. The means with the same letter at any position were not significantly different $(\mathrm{P}>0.05)$ 


\section{REFERENCES}

1. AOAC 2007. Association of Official Analytical Chemists. Official Method of Analysis. $\left(18^{\text {th }}\right.$ Ed.), pp. 302-850. Benjamin Franklin Station Washington, D.C., USA.

2. AOAC. 2012. Association of Official Analytical Chemists. Official Method of Analysis. (19 ${ }^{\text {th }}$ Ed. $)$, pp. 9-13.

3. Ceirwyn S. J. 1995. Analytical Chemistry of Foods. Part Iin book.p.135.

4. Codex Alimentarius Commission of FAO/WHO. 2002. Proosed Draft Revised Standard for Fermented Milk Products. Pp. 52-80. CCMMP, Food and Agriculture Organization of the United Nations, Rome.

5. Chou, W.T., SheihI.C. and FangT.J. 2013. The applications of polysaccharides from various mushroom wastes as prebiotics in different systems. J. of Food Sci., 78: 1041-1048.

6. Dave, R.I.and Shah N. P. 1996. Evaluaton of media for selective enumeration of Streptococcus thermophilus, Lactobacillus delbrueckii ssp. bulgaricus, Lactobacillus acidophilus and bifidobacteria. J. Dairy Sci., 79: 1529-1536.

7. Dervisoglu, M. and Yazici, F. 2006. The effect of citrus fibre on the physical, chemical and sensory properties of ice cream. Food Sci. Technol.Int., 12:159.

8. EOSQ 2010. Egyptian Organization for Standardization and Quality. Egyptian Standard. D-1 Food/2010. Guide Lines for Quality Criteria for Milk and Milk Products.

9. FDA 2013. U.S. Food and Drug Administeration. Center for Food Safaty and Applied Nutrition. Guidance for Industry: A Food Labeling Guide. January 2013.

10. Gibson, G. R. 1999. Dietary modulation of the human gut microflora using the prebiotic inulin and oligofructose. J. Nut. 129: $1438 \mathrm{~S}-1441 \mathrm{~S}$.

11. Gueimonde, AlonsoM., L., DelgadoT., Bada-GancedoJ. C. and Reyes-GavilanC. (2003).Quality of plain yoghurt made from refrigerated and $\mathrm{CO}_{2}$-treated milk. Food Res. Int., 36:43-48.

12. Husein, Y.A., Aita O.A., Fayed A. E. and EL-Nawawy M.A. 2006. Effect of transglutaminase on the quality of yoghurt made with different milk protein sources. $10^{\text {th }}$ Conf. Agric. Dev. Res., Ain Shams Univ., Cairo, Nov., 6-8. Annals Agric. Sci., Sp. Issue, 1:111-122.

13. Jalili, T., Wildman, R. E. C. and Medeiros, D. M. 2000. Nutraceutical roles of dietary fiber. Journal of Nutraceuticals, Functional and Medical Foods, 2, 19 -34. 
14. Lindequist, U., Niedermeyer, T.H.J., and Julich, W.D. 2005. The pharmacological potential of mushrooms. Evidence- Based Complementary and alternative Medicine 2,285- 299.

15. Mattila -Sandholm, T., Myllarnen, P., Crienden ,R ., Mogensen ,G., Fonden ,R. and SaarelaM. 2002. Technological challenges for future probiotic foods. Int. Dairy J. 12: $173-182$.

16. Nelson, A. L. 2001. High-Fiber Ingredients. St. Paul, MN: Eagan.

17. Pantulu , P . C ., Bhimasena , Rao , M., SehuRoa , D. and Anantakrishman , C. P 1975. Application of liberman - Burchard reaction to the unsaponifiable portion of milk lipids as a criterion for the quantitative determination of cholesterol in milk and milk products . Mildiwissenschaft 30 (12) $735-738$.

18. Rasic, J.L. and J.A. Kurmann (Eds.) 1978. Yoghurt, Scientific Grounds, Technology, Manufacture and Preparations. pp. 17-68. Tech. Dairy Pub. House, Copenhagen, Denmark.

19. Sun, M. T., Xiao, J. T., Zhang, S. Q., Liu, Y. J. and Li, S. T. 1984. Therapeutic effect of some foods on hyperlipidermia in man. Acta Nutritional Sinica, 6, 127 133.

20. SAS, 1996. Statistical Analysis System. SAS user's guide. Satatistics. SAS Inst. Inc. Ed., Cary, NC, U.S.A.

21. Tamime, A.W. and Robinson, R. K. 1999. Yoghurt science and technology. Cambridge, GB: CRC press, Woodhead publishing Ltd.

22. Verma, A., Keshervani, G. P., Sharma, Y. K., Sawarkar, N. J., and Singh, P. 1987. Mineralcontent of edible (dehydrated) mushrooms. Indian Journal of Nutrition and Dietitians,24, 241-245.

23. Vinderola C. G, Bailo $\mathrm{N}$ and Reinheimer J. A. 2000. Survival of probiotic microflora in Argentinian yoghurts during refrigerated storage. Food Res. Int. 33: 97. 


\section{دراسة عن الزبادى المدعم بالمشروم}

\section{أمل إبر اهيم الدرديرى1، فتحى أنور عبد المالكك 1 و رحاب حامد جاب الله2}

1. قسم كيمباء الألبان، معهز بحوث الإنتاج الحيوانى، مركز البحوث الزراعية، جيزة، مصر.

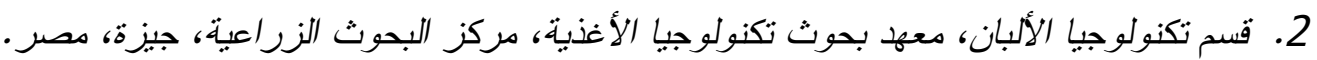

استهدف البحث دراسة تدعيم الزبادى بالمشروم ذو القيمة الغذائية و الصحية. حيث تم تدعيم

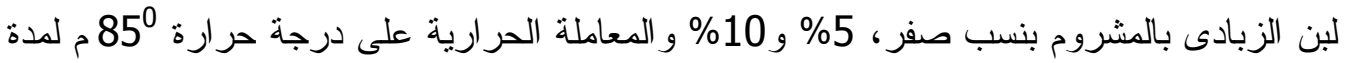

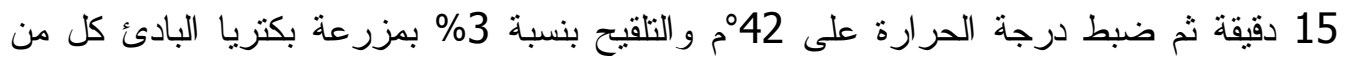

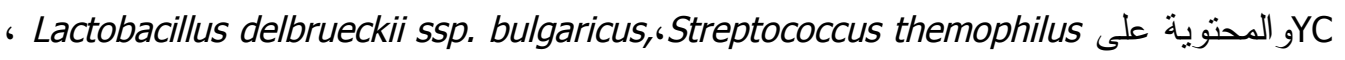
Streptococcus themophilus, Lactobacillus delbrueckii, ssp. bulgaricus المحتوية على YL Streptococcus themophilus, Lactobacillus المحتوية على YB و Lb. acidophilus، Bifidobacterium bifidum, delbrueckii ssp. bulgaricus,

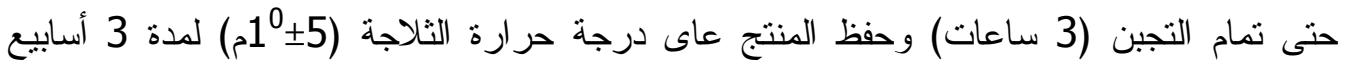
و اجريت الاختبار ات الكيميائية ،الميكروبية ،الريولوجية والحسية بالاضافة الى تقدير القيمة الغذائية.

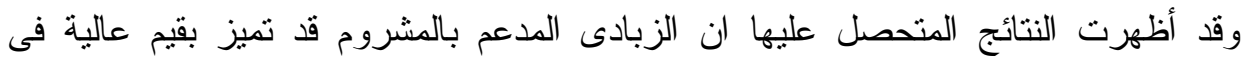
البروتين، الرماد، الالياف، الــPH، اللزوجة ،الاحماض الامينية، الفيتامينات، الاملاح المعدنبة،

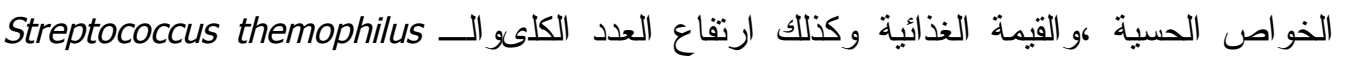
Bifidobacterium bifidum, Lb. acidophilus, Lactobacillus delbrueckii ssp. bulgaricuss,

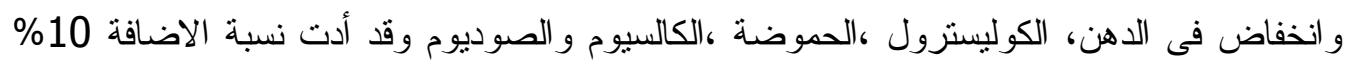

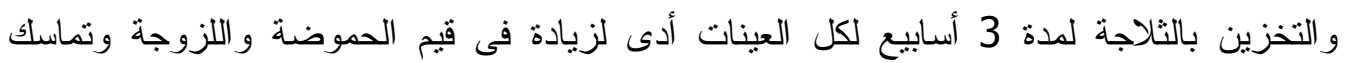

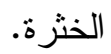
ومن النتائج السابقة يمكن أستتتاج ان الزبادى بجانب كونه منتج غذائى حيوى فأنه يمكن زيادة

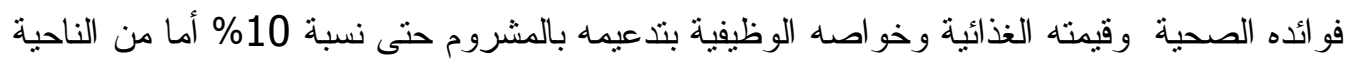

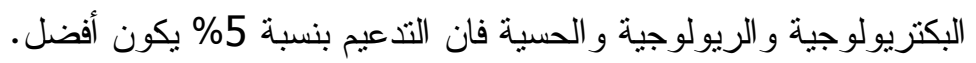

